DOI: $10.19195 / 0137-1134.114 .3$

\author{
ADAM BŁAŚS \\ Uniwersytet Wrocławski \\ adam.blas@uwr.edu.pl
}

\title{
PROBLEM SAMODZIELNOŚCI ORGANU ADMINISTRACYJNEGO W ŚWIETLE IDEI PAŃSTWA PRAWNEGO
}

\begin{abstract}
Abstrakt: W doktrynie prawa administracyjnego i w nauce administracji problem samodzielności działania administracji badano na tle idei państwa prawnego. W klasycznej nauce prawa administracyjnego przyjęto pogląd, iż zasadniczą postacią samodzielności organu administracyjnego jest tak zwana sfera uznania administracyjnego. Nie jest ono jednak jedyną postacią samodzielności działania administracji, gdyż normy administracyjnego prawa materialnego, ustrojowego i procesowego dopuszczają zróżnicowane uprawnienia administracji do samodzielnego działania.
\end{abstract}

Słowa kluczowe: organ administracji, samodzielność, uznanie administracyjne, państwo prawne

Idea państwa prawnego kształtująca się w Europie na przełomie XIX i XX wieku wyrastała z przekonania, że państwo rządzone prawem zapewni obywatelowi ochronę prawną przed dowolnością, arbitralnością i samowolą władzy administracyjnej ${ }^{1}$.

Sądzono, że dowolność i arbitralność tej władzy winna być ograniczona, a przynajmniej zredukowana przez ujęcie całej aktywności administracyjnej w szranki prawne, ściślej zaś związanie tej działalności normami prawa powszechnie obowiązującego.

Wypada tu zauważyć, że w okresie poprzedzającym państwo praworządne władza administracyjna nie była kształtowana ze względu na prawo. Natomiast dość powszechnie twierdzono, że prawo nie może wiązać panującego wobec jego ius politiae, władca i jego aparat rządzi się swobodnym uznaniem i dysponuje nieograniczoną władzą jako administrator interesu publicznego ${ }^{2}$.

1 M. Zimmermann, Pojęcie administracji publicznej a „swobodne uznanie”, Poznań 1959, s. $9 \mathrm{n}$.

2 Ibidem, s. 27 n. 
Jak pisał J.S. Langrod, administrację tworzono jako instrument rządzenia i rozkazywania ${ }^{3}$. Postulat ograniczenia prawem rządzenia i rozkazywania był w tamtych odległych czasach raczej niezrozumiały, gdyż panowało mocne przekonanie, że istotą administrowania jest swoboda rządzenia i rozkazywania ${ }^{4}$. Przeciwnicy idei prawnego związania aktywności administracyjnej twierdzili, że administracja jest działalnością zupełnie niezależną od prawa, mogącą istnieć nawet bez porządku prawnego, gdyż administracja jest pojęciem gospodarczym, nie zaś prawnym. H. Kelsen pisał, że administracja w pierwotnym znaczeniu oznacza działalność zmierzającą do pewnego celu, jest zarządzaniem pewną ilością dóbr z dążeniem do ich pomnożenia, a przynajmniej do ich utrzymania ${ }^{5}$. J.S. Langrod stwierdził, że „trzeba było pokonania licznych oporów i dużego przewrotu myślowego, aby oprzeć aktywność administracyjną na stałej bazie prawnej i przez to uczynić z niej jedno z ogniw porządku prawnego"6.

Idea związania prawnego działalności administracyjnej — choć nie bez zastrzeżeń - torowała sobie drogę w całej Europie. Rychło się jednak okazało, że w praktyce nie jest możliwe ujęcie całej działalności administracyjnej w normach prawa, że trzeba pozostawić administracji jakieś nieliczne zakresy swobo$\mathrm{dy}^{7}$. W ten sposób w doktrynie prawa administracyjnego i w nauce administracji pojawił się problem samodzielności działania administracji. Problem ten należało rozwiązać zgodnie z ideą państwa prawnego. Najwcześniejsze rozwiązania wskazanego problemu wiążą się $\mathrm{z}$ dyskusją, jaką toczono na temat charakteru działalności administracyjnej. W literaturze naukowej stopniowo narastał pogląd, że administracja nie może być postrzegana jako wykonywanie ustaw, bo jej istotą jest działalność twórcza. G. Renard pisał, że twórczy pierwiastek w działalności administracyjnej jest jej conditio sine qua non ${ }^{8}$.

Wspomniany już H. Kelsen stwierdził, że działania administracji państwa nigdy nie są w całości w porządku prawnym przewidziane. Zarówno warunki, wśród których państwo chce działać, jak i rodzaj i sposób samego działania nie są nigdy wszechstronnie w normie prawnej określone i raczej należy przyjąć, że w ocenie w danym konkretnym przypadku istnieją założenia woli państwowej i czy dają organowi zobowiązanemu do jej urzeczywistnienia węższe czy szersze ramy, organ ten, w tym czy owym kierunku swego zachowania, nie jest skrępowany9 ${ }^{9}$. Podobną argumentację znajdziemy w pracach polskich uczonych. Dopuszczali

3 J.S. Langrod, Instytucje prawa administracyjnego, zarys części ogólnej, Kraków 2003, reprint, s. 35.

${ }^{4}$ Pisze o tym F. Fleiner, Institutionen des Deutsche Verwaltungsrechts, Tübingen 1928, s. 30.

5 H. Kelsen, Podstawowe zagadnienia nauki prawa państwowego, t. 2, Wilno 1936, s. 208.

6 J.S. Langrod, op. cit., s. 35.

7 T. Hilarowicz, Zasada swobodnego ocenienia $w$ nauce administracji $i$ w prawie administracyjnym austriackim, Lwów 1917, s. 33; W.S. Wachholz, Zasada swobodnej oceny władzy administracyjnej w państwie prawnym, Kraków 1929.

8 G. Renard, Le droit, la logique et le bon sens, Paris 1925, s. 362.

9 H. Kelsen, op. cit., s. 220. 
sytuacje, w których prawo powszechnie obowiązujące pozostawia administracji pewne zakresy swobody działania. W.L. Jaworski, odmiennie od pozostałych przedstawicieli nauki prawa administracyjnego, twierdził, że nie cała działalność administracji jest uregulowana prawem. Uczony ten pisał, że ,uregulowana jest ta działalność, która dotyczy porządku publicznego"10.

W klasycznej nauce prawa administracyjnego przyjęto pogląd, iż zasadniczą postacią samodzielności organu administracyjnego jest tak zwana sfera uznania administracyjnego. Jest to sfera, w której organ administracyjny podejmuje decyzję na podstawie normy prawnej blankietowej, może samodzielnie ustalić treść tej decyzji ${ }^{11}$. Początkowo sądzono, że ten typ samodzielności działania organu administracyjnego to pewien konieczny relikt państwa policyjnego, czyli państwa, w którym administracja miała swobodę działania. Uznanie administracyjne, o którym mowa, do dziś ocenianie jest niejednoznacznie. Jak pisze I. Bogucka, w radykalnej wersji państwa prawnego uznanie organu jest postrzegane jako „furtka, którą może uciec nasza wolność"12. Wypada jednak wyraźnie podkreślić, że tak dalece krytyczne stanowisko doktryny nie jest już dominujące.

W doktrynie wskazuje się, że uznanie nie jest jedyną postacią samodzielności działania administracji1 ${ }^{13}$, gdyż normy administracyjnego prawa materialnego, ustrojowego i procesowego dopuszczają zróżnicowane uprawnienia administracji do samodzielnego działania. Przede wszystkim są to uprawnienia do ustalania celów i zadań administracji, do dokonywania wyboru decyzji, do projektowania wariantów działania, do tworzenia norm organizacyjnych niemających charakteru prawnego, inicjowania działań niewładczych itp.

J. Zimmermann pisze, że dyskrecjonalne są subiektywne ustalenia stanu faktycznego, także wykładnia każdego przepisu jest dyskrecjonalna, poszukiwanie i weryfikowanie materiału dowodowego. Zdaniem tego autora dyskrecjonalność i uznanie administracyjne stanowią jedne $\mathrm{z}$ najważniejszych filarów i aksjomatów prawa administracyjnego ${ }^{14}$.

W badaniach z zakresu nauki administracji widoczny jest wzrost znaczenia dyskrecjonalności administracji publicznej. Dyskrecjonalność obejmuje nie tylko

10 W.L. Jaworski, Nauka prawa administracyjnego. Zagadnienia ogólne, Warszawa 1924, s. 124.

11 J. Starościak, Swobodne uznanie władz administracyjnych, Warszawa 1948; M. Mincer, Uznanie administracyjne, Torun 1983; M. Jaśkowska, Uznanie administracyjne a inne formy władzy dyskrecjonalnej administracji publicznej, [w:] System Prawa Administracyjnego, t. 1. Z. Duniewska et al., Instytucje prawa administracyjnego, Warszawa 2010. Zob. też Z. Duniewska, Istota i granice dyskrecjonalnej władzy administracyjnej $w$ świetle standardów europejskich, „Studia Prawno-Ekonomiczne" 59, 1999.

12 I. Bogucka, Państwo prawne a problem uznania administracyjnego, „Państwo i Prawo” 1992, nr 10, s. 43.

13 A. Błaś, Konstrukcje prawne dyskrecjonalnych uprawnień administracji publicznej we współczesnym prawie administracyjnym, „Samorząd Terytorialny” 2000, nr 5, s. 59.

14 J. Zimmermann, Aksjomaty prawa administracyjnego, Warszawa 2013, s. 203. 
procesy stosowania prawa, lecz także procesy stanowienia tego prawa. Znane jest na przykład pojęcie dyskrecjonalności legislacyjnej, które polega na stanowieniu przez ustawodawcę takich , upoważnień do wydawania przez organy administracyjne rozporządzeń, że organy te swobodnie decydują, w jaki sposób i poprzez jaką merytorycznie regulację, można wykonać ustawę macierzystą"15.

Dodajmy, że w literaturze naukowej znane jest także pojęcie arbitralności prawa, ściślej zaś arbitralności normy prawnej. $Z$ arbitralnością prawa mamy do czynienia wtedy, gdy brakuje racjonalnego uzasadnienia tej normy ${ }^{16}$.

Na koniec wypada zauważyć, że praktyka administracyjna zna też zjawisko używania przez administrację przepisów prawa do osiągania bieżących, doraźnych celów (instrumentalizacja prawa). Zjawisko instrumentalizacji jest obecnie oceniane krytycznie, gdyż instrumentalizacja gubi prymat prawa jako wartość państwa prawnego. Stanowi zagrożenie stałości i pewności sytuacji prawnej obywatela.

\section{PROBLEM OF INDEPENDENCE OF THE ADMINISTRATIVE ORGAN IN THE LIGHT OF THE IDEA OF A STATE OF LAW}

\section{Summary}

In the science of administrative law and the science of administration, the problem of independence of administration was examined against the background of the idea of a state of law. In the classical science of administrative law, the view was taken that the main form of independence of the administrative organ is the so-called sphere of administrative discretion. However, it is not the only form of independence of the administration, because the norms of administrative substantive law, systemic law and procedural law allow for various administrative powers to act independently.

Keywords: administrative organ, independence, administrative discretion, state of law

\section{BIBLIOGRAFIA}

Błaś A., Konstrukcje prawne dyskrecjonalnych uprawnień administracji publicznej we wspótczesnym prawie administracyjnym, „Samorząd Terytorialny” 2000, nr 5.

Bogucka I., Państwo prawne a problem uznania administracyjnego, „Państwo i Prawo” 1992, nr 10.

Duniewska Z., Istota i granice dyskrecjonalnej władzy administracyjnej w świetle standardów europejskich, „Studia Prawno-Ekonomiczne” 59, 1999.

Fleiner F., Institutionen des Deutsche Verwaltungsrechts, Tübingen 1928.

Hilarowicz T., Zasada swobodnego ocenienia w nauce administracji $i$ w prawie administracyjnym austriackim, Lwów 1917.

15 Ibidem, s. 213.

16 J. Supernat, Arbitralność prawa, [w:] Jakość prawa administracyjnego, red. D.R. Kijowski, A. Miruć, A. Suławko-Karetko, Warszawa 2012, s. 45. 
Jaśkowska M., Uznanie administracyjne a inne formy władzy dyskrecjonalnej administracji publicznej, [w:] System Prawa Administracyjnego, t. 1. Z. Duniewska et al., Instytucje prawa administracyjnego, Warszawa 2010.

Jaworski W.L., Nauka prawa administracyjnego. Zagadnienia ogólne, Warszawa 1924.

Kelsen H., Podstawowe zagadnienia nauki prawa państwowego, t. 2, Wilno 1936.

Langrod J.S., Instytucje prawa administracyjnego, zarys części ogólnej, Kraków 2003, reprint.

Mincer M., Uznanie administracyjne, Toruń 1983.

Renard G., Le droit, la logique et le bon sens, Paris 1925.

Starościak J., Swobodne uznanie władz administracyjnych, Warszawa 1948.

Supernat J., Arbitralność prawa, [w:] Jakość prawa administracyjnego, red. D.R. Kijowski, A. Miruć, A. Suławko-Karetko, Warszawa 2012.

Wachholz W.S., Zasada swobodnej oceny władzy administracyjnej w państwie prawnym, Kraków 1929.

Zimmermann J., Aksjomaty prawa administracyjnego, Warszawa 2013.

Zimmermann M., Pojęcie administracji publicznej a ,swobodne uznanie”, Poznań 1959. 